\author{
EESTI NSV TEADUSTE AKADEEMIA TOIMETISED. XII KOIDE \\ FOOSIKA-MATEMAATIKA- JA TEHNIKATEADUSTE SEERIA. 1963, NR. 4
}

ИЗВЕСТИЯ АКАДЕМИИ НАУК ЭСТОНСКОЙ ССР. ТОМ ХІІ СЕРИЯ ФИЗИКО-МАТЕМАТИЧЕСКИХ И ТЕХНИЧЕСКИХ НАУК. 1963, № 4

\title{
О ХИМИЧЕСКОМ СОСТАВЕ СМОЛЫ БРАЗИЛЬСКОГО ГОРЮЧЕГО СЛАНЦА
}

\author{
О. ЭИЗЕН, К. ХЕЛЬП, \\ кандндаты технических наук
}

В начале 1961 г. на Сланцеперерабатывающем комбинате им. В. И. Ленниа г. Кохтла-Ярве Эстонской ССР были проведены промышленные испытания по газификации бразильского горючего сланца с целью определения технической возможности производства высококалорнйного газа на базе бразильского сланца.

Переработка бразильского сланца осуществлялась в опытно-промышленных камерных печах по технологической схеме, принятой для эстонского горючего сланца. Температура в обогревательных простенках камеры выдерживалась около $1285^{\circ} \mathrm{C}$, причем фактическая температура переработки сланца внутри камеры в среднем не превышала $750^{\circ} \mathrm{C}$. При этих испытаннях были подробно сняты все показатели технологических режимов работы камерных печей и определены характеристики' вырабатываемых продуктов кроме свойств и состава смолы.

В настоящей работе приводятся данные, характеризующие химический состав смоды бразильского сланца. В качестве исходного материала для исследования служила суммарная смола, отобранная из системы конденсации. Основные данные, характеризующие исходную смолу, таковы:

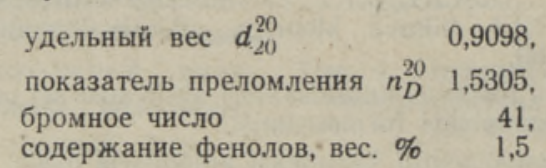

Исходная смола была разогнана на фракции. Выход фракций и остаток дистилляции составляли, соответственно, 49,8 и $50,2 \%$.

Выкипающие до $200^{\circ}$ бензиновые фракции, выход которых составлял $15,5 \%$ в пересчете на суммарную смолу, были объединены и для них определялись следующие показатели:

удельный вес $d_{20}^{20}$

показатель преломления $n_{D}^{20}$

бромное число

содєржание кислых соединений, вес. \% содержание серы, вес. \%

содержанне азота, вес. \%

Химический групповой состав бензина определялся силикагеле.
Групповой состав, вес. \%:

парафиновые углеводороды
олефиновые углеводороды
ароматические углеводороды, кисло-
родные и сернистые соединения

Пределы. кипения:

начало кипения, ${ }^{\circ} \mathrm{C}-80$, $10 \%$ выкипает до 136, $50 \%$ выкипает до 159 , $90 \%$ выкипает до 192, конец кипения 214 .

хроматографированием на

Основные индивндуальные углеводороды определялись посредством газохроматографии на хроматографе УХ-1 Таллинского завода измерительных приборов. При анализе парафиновых и олефиновых углеводородов применялись 3-7-метровые колонки. 
наполненные дифенилформамидом на диатомите. Ароматические углеводороды были определены на $\beta, \beta^{\prime}$-тиодипропионитриле. Рабочая температура в колонке составляла $100-150^{\circ}$. Скорость пропускаемого водорода равнялась $50 \mathrm{mл/мuн.}$ При интерпреташии хроматографических пиков были использованы синтезированные в Инстигуте химии АН ЭССР эталонные соединения. Результаты анализа приведены в табл. 1 .

Из данных табл. 1 видно, что углеводороды, содержащиеся в бензиновых фракщиях, полученных в результате газификации бразильского горючего сланца при температуре 700 $750^{\circ}$, представлены прежде всего в виде ароматических соединений. Ввиду того, что система конденсации опытной установки не обеспечивала полного улавливания легких фракций, в бензине содержится сравнительно мало бензола и других низкокипящих соединений. В данном случае среди ароматических углеводородов доминируют в бензине толуол и ксилолы, общее количество которых составляет около $30 \%$ от суммарного бензина. Основными олефиновыми углеводородами являются н. нонены и н. децены, составляющие свыше $50 \%$ от фракции олефиновых углеводородов и около $18 \%$ от бензина. Остальные углеводороды не имеют какого-либо решающего количественного значения. Известно, что соединения с разветвленной цепью термически менее стабильны, чем нормальные [1, 2]. Поэтому при термической переработке при температуре $700-750^{\circ} \mathrm{C}$ большая часть изоструктурных соединений переходит в газ или ароматические соединения, в основном сохраняются только парафиновые и олефиновые углеводороды нормального строения. Аналогичное распределение углеводородов имеет место и в жидких продуктах термической переработки эстонского горючего сланца, осуществляемой в температурном интервале $700-750^{\circ}\left[{ }^{3}\right]$. Из алифатических соединений здесь также сохраняются соединения нормального строения.

Характеристика дистиллированных средних и тяжелых фракций приведена в табл. 2.

Групповой состав фракций (см. табл. 2) был определен хроматографированием на силикагеле. Хроматографическое разделение осуществлялось по элюентному методу. Соотношение смолы и силикагеля составляло $1: 10$, в качестве элюента применялись петролейный эфир, бензол и ацетон или этиловый спирт. Peзультаты анализа представлены в табл. 3 .

Из данных табл. 3 видно, что тяжелые фракцин жидких продуктов, полученных в результате газификации бразильского сланца, состоят
Таблица 1

Химический состав бразильского саанцевого бензина

\begin{tabular}{|c|c|c|}
\hline \multirow{2}{*}{$\begin{array}{c}\text { Идентифици- } \\
\text { рованные } \\
\text { соединения }\end{array}$} & \multicolumn{2}{|c|}{$\begin{array}{c}\text { Содержание, } \\
\text { вес. \% }\end{array}$} \\
\hline & $\begin{array}{c}\text { в группе } \\
\text { углево- } \\
\text { дородов }\end{array}$ & $\begin{array}{l}\text { в сум- } \\
\text { марном } \\
\text { бензнне }\end{array}$ \\
\hline \multicolumn{3}{|l|}{$\begin{array}{c}\text { Предельные } \\
\text { углеводороды }\end{array}$} \\
\hline $\begin{array}{l}\mathrm{C}_{7} \\
\mathrm{C}_{8} \\
\mathrm{C}_{9} \\
\mathrm{C}_{10} \\
\mathrm{C}_{11} \\
\mathrm{C}_{12} \\
\mathrm{C}_{13} \\
\mathrm{C}_{14} \\
\mathrm{C}_{15} \\
\text { Прочие }\end{array}$ & $\begin{array}{r}2,2 \\
9,8 \\
23,2 \\
29,3 \\
20,6 \\
8,9 \\
3,0 \\
2,0 \\
0,5 \\
0,5\end{array}$ & $\begin{array}{l}0,2 \\
1,1 \\
2,5 \\
3,1 \\
2,2 \\
1,0 \\
0,3 \\
0,2 \\
0,05 \\
0,05\end{array}$ \\
\hline Bcero & 100,0 & 10,7 \\
\hline $\begin{array}{c}\text { Олефнновые } \\
\text { углеводороды } \\
\mathrm{C}_{6} \\
\mathrm{C}_{7} \\
\mathrm{C}_{8} \\
\mathrm{C}_{9} \\
\mathrm{C}_{10} \\
\mathrm{C}_{11} \\
\mathrm{C}_{12} \\
\text { Прочие } \\
\end{array}$ & $\begin{array}{r}0,6 \\
3,4 \\
10,0 \\
25,4 \\
28,1 \\
9,4 \\
3,9 \\
19,2 \\
\end{array}$ & $\begin{array}{l}0,2 \\
1,0 \\
3,0 \\
7,6 \\
8,4 \\
2,8 \\
1,2 \\
5,7 \\
\end{array}$ \\
\hline Bcero & 100,0 & 29,9 \\
\hline $\begin{array}{l}\text { Ароматические } \\
\text { углеводороды } \\
\text { Бензол } \\
\text { Толуол } \\
\text { Этилбензол } \\
\text { Пропилбензол } \\
\text { м+п-Ксилол } \\
\text { о-Ксилол } \\
\text { 1,3 + 1,4-Ме- } \\
\text { тилэтилбензол } \\
\text { 1,2-Метилэтил- } \\
\text { бензол } \\
\text { 1,3,5-Триметил- } \\
\text { бензол } \\
\text { 1,2,4-Триметил- } \\
\text { бензол } \\
\text { 1,2,3-Триметил- } \\
\text { бензол } \\
\text { Индан } \\
\text { Нендентифи- } \\
\text { цированы }\end{array}$ & $\begin{array}{r}4,5 \\
18,8 \\
5,7 \\
1,7 \\
17,1 \\
19,5 \\
1,9 \\
3,7 \\
2,6 \\
8,5 \\
5,6 \\
3,2 \\
7,2\end{array}$ & $\begin{array}{r}2,4 \\
10,1 \\
3,1 \\
0,9 \\
9,2 \\
11,5 \\
1,0 \\
2,0 \\
1,4 \\
4,6 \\
3,0 \\
1,7 \\
3,9\end{array}$ \\
\hline Bcero & 100,0 & 53,8 \\
\hline \multicolumn{2}{|c|}{$\begin{array}{l}\text { Сернистые соединения } \\
\text { Кислородные соединения }\end{array}$} & $\begin{array}{l}3,6 \\
2,0\end{array}$ \\
\hline & Bcero & 100,0 \\
\hline
\end{tabular}


Характеристика фракций бразильской сланцевой смолы

\begin{tabular}{|c|c|c|c|c|c|c|c|c|c|c|c|}
\hline \multirow[b]{2}{*}{ 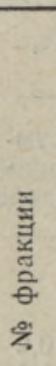 } & \multirow{2}{*}{ 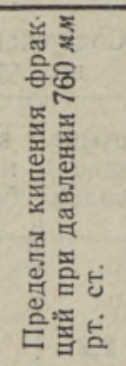 } & \multirow[b]{2}{*}{ 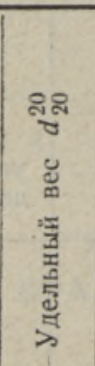 } & \multirow{2}{*}{ 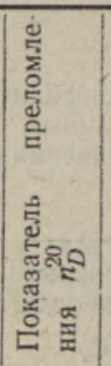 } & \multirow[b]{2}{*}{ 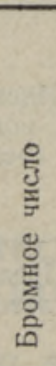 } & \multirow[b]{2}{*}{ 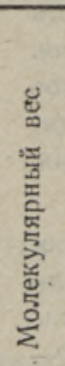 } & \multirow{2}{*}{ 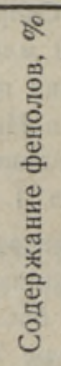 } & \multicolumn{4}{|c|}{ Элементарный состав, \% } & \multirow{2}{*}{ 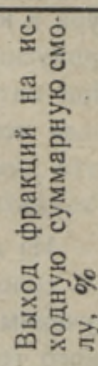 } \\
\hline & & & & & & & C & $\mathrm{H}$ & S & $\mathrm{O}+\mathrm{N}$ & \\
\hline $\begin{array}{r}3 \\
4 \\
5 \\
6 \\
7 \\
8 \\
9 \\
10 \\
11\end{array}$ & $\begin{array}{l}160-183 \\
183-192 \\
192-212 \\
212-225 \\
225-247 \\
247-266 \\
266-290 \\
281-310 \\
293-343\end{array}$ & $\begin{array}{l}0,8324 \\
0,8583 \\
0,8881 \\
0,8946 \\
0,9034 \\
0,9042 \\
0,9021 \\
0,9072 \\
0,9162\end{array}$ & $\begin{array}{l}1,4771 \\
1,4873 \\
1,5050 \\
1,5165 \\
1,5172 \\
1,5160 \\
1,5145 \\
1,5175 \\
1,5205\end{array}$ & $\begin{array}{l}43 \\
43 \\
40 \\
35 \\
31 \\
29 \\
29 \\
26 \\
26\end{array}$ & $\begin{array}{l}113 \\
123 \\
141 \\
145 \\
146 \\
172 \\
183 \\
200 \\
205\end{array}$ & $\begin{array}{l}1,4 \\
3,3 \\
4,1 \\
3,1 \\
2,4 \\
1,4 \\
1,7 \\
2,2 \\
2,1\end{array}$ & $\begin{array}{l}86,80 \\
87,22 \\
88,00 \\
88,20 \\
87,90 \\
87,60 \\
87,05 \\
86,80 \\
87,20\end{array}$ & $\begin{array}{l}11,60 \\
11,34 \\
11,00 \\
10,51 \\
10,63 \\
10,88 \\
11,18 \\
11,22 \\
11,17\end{array}$ & $\begin{array}{l}0,41 \\
0,38 \\
0,57 \\
0,87 \\
0,83 \\
0,87 \\
0,50 \\
0,57 \\
0,55\end{array}$ & $\begin{array}{l}1,19 \\
1,06 \\
0,43 \\
0,51 \\
0,64 \\
0,65 \\
1,27 \\
1,41 \\
1,08\end{array}$ & 4,2 \\
\hline
\end{tabular}

в основном из ароматических углеводородов. Содержание их в отдельных фракциях превышает $50 \%$, максимальная же концентрация имеет место во фракции $212-225^{\circ}$ и достигает $66,5 \%$. В ходе хроматографирования из фракции ароматических соединений выпадал кристаллический нафталин, который идентифицировался по его ультрафиолетовому спектру.

Концентрат ароматических углеводородов фракций $281-310^{\circ}$ и $293-343^{\circ}$ разбавляли гексаном и охлаждали до $-75^{\circ}$, в результате чего из него выпадала кристалли-

Групповой состав бразильской сланцевой смолы

\begin{tabular}{|c|c|c|c|c|c|}
\hline \multirow[b]{2}{*}{ 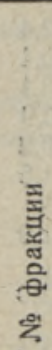 } & \multirow[b]{2}{*}{$\begin{array}{l}\text { Пределы } \\
\text { кипения }\end{array}$} & \multicolumn{4}{|c|}{ Групповой состав, вес. \% } \\
\hline & & 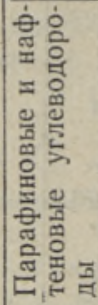 & 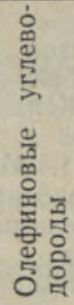 & 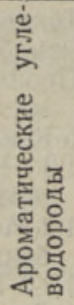 & $\begin{array}{l}5 \\
5 \\
= \\
= \\
0 \\
3 \\
5 \\
5 \\
0 \\
\frac{3}{4}\end{array}$ \\
\hline $\begin{array}{l}10 \\
11\end{array}$ & $\begin{array}{l}160-183 \\
183-192 \\
192-212 \\
212-225 \\
225-247 \\
247-266 \\
266-290 \\
281-310 \\
293-343\end{array}$ & $\begin{array}{l}17,6 \\
16,8 \\
16,5 \\
15,4 \\
16,6 \\
18,7 \\
21,8 \\
24,6 \\
22,7\end{array}$ & $\begin{array}{r}18,7 \\
15,9 \\
10,8 \\
11,4 \\
9,7 \\
10,6 \\
12,6 \\
13,8 \\
10,3\end{array}$ & $\begin{array}{l}43,7 \\
51,8 \\
53,4 \\
66,5 \\
54,4 \\
55,5 \\
51,1 \\
50,0 \\
44,9\end{array}$ & $\begin{array}{l}14,0 \\
11,6 \\
22,1\end{array}$ \\
\hline
\end{tabular}
ческая часть, которую впоследствии отделяли фильтрованием при низкой температуре. Для кристаллов были определены ультрафиолетовые спектры. Во фракциях $281-310^{\circ}$ встречаются соединения типа дифеннла; во фракции $293-343^{\circ}$ было доказано присутствие фенантрена и антрацена. Во фракциях 225-266 ${ }^{\circ}$ встречают ся метилнафталины и ряд диметилнафталинов.

Если для фракций эстонской сланцевой смолы характерно с ростом пределов кипения постоянное уменьшение содержания парафиновых, нафтеновых и олефиновых углеводородов, то с бразильским сланцем нам представляется противоположная картина - содержание парафнновых углеводородов возрастает в сторону вышекнпящих фракций. Содержание же олефиновых углеводородов, в температурном пределе $192-343^{\circ}$, остается почти постоянным, составляя около $10 \%$.

Для более подробной характеристи кн концентрата олефиновых углеводородов, полученных посредством хрома тографического разделения (табл. 2), концентрат подвергался инфра- 
красному спектральному анализу, который осуществлялся на двухлучевом спектрофотометре ИКС-14 в пределах волновых чисел 2000-680 см-'. Результаты спектрально-аналитического исследования показывают, что как в бензиновых, так и в тяжелых фракциях олефиновые углеводороды представлены в основном в виде соединений типа $-\mathrm{CH}=\mathrm{CH}-$ (транс), о чем свидетельствует сильный максимум в пределе $965 \mathrm{~cm}^{-1}$.

Наличие интенсивного максимума в пределе $724 \mathrm{~cm}^{-1}$ указывает на присутствие длинных алифатических цепей.

Можно полагать, что средние и тяжелые фракцин высокотемпературной смоли бразильского сланца содержат в основном олефнновые углеводороды нормального строения, имеющие при этом двойную связь в большинстве случаев в середине, а не на концах цепи.

Кислородные и азотистые соединения представляют собой жидкости темнокоричневого цвета с характерным запахом и составляют 15-20\% от суммарной смолы,

\title{
Л ИТЕ РАТ У РА
}

1. A. N. S a ch a n e n, Conversion of Petroleum. Reinhold Co. New York, 1948, 496-501.

2. B. S. Greensfeld er, H. H. Vog e, C. M. G o od, Ind. Eng. Chem., 1949, 41, 2573.

3. И. Р. Клесмент, Э. Х. Арумеел, Изв. АН ЭССР. Сер. техн. и физ.матем. наук, $1959,3,180-185$.

Институт химии

Академии наук Эстонской ССР
Поступнла в редакцию

28. V 1963

\section{BRASIILIA POLLEVKIVIÖLI KEEMILISEST KOOSSEISUST}

\author{
O. Eisen, \\ tehnikateaduste kandidaat \\ K. Help
}

Resümee

Kohtla-Järve kamberahjudes brasiilia põlevkivi gaasistamiskatsetel saadud tõrva koosseis määrati kromatograafilistel meetoditel.

Brasiilia pōlevkivibensiini individuaalne koosseis määrati gaasikromatograafilisel meetodil. Keskmiste ja raskete fraktsioonide kohta esitatakse grupikoosseisu andmed.

Eesti NSV Teaduste Akadeemia
Keemia Instituut

\section{OBER DIE CHEMISCHE ZUSAMMENSETZUNG DES BRASILIANISCHEN BRENNSCHIEFERTEERS}

\section{Q. Eisen, K. Help \\ Zusammenfassung}

Vorliegende Arbeit bringt die physikalisch-chemische Charakteristik des in den Kammeröfen von Kohtla-Järve bei Gasifizierungsversuchen gewonnenen brasilianischen Brennschiêferteers nebst Angaben über seine Gruppenzusammensetzung.

Die individuelle Zusammensetzung der Benzinfraktionen wurde mit Hilfe der Gaschromatographie, eine Gruppenzusammensetzung der Fraktionen, die den Bereich über $2 \cup 0^{\circ}$ umiassen, auf chromatographischem Wege bestimmt.

\footnotetext{
Institut für Chentie

der Akademie der Wissenschaften der Estnischen SSR

5. ENSV TA Toimetised $\mathrm{T}-463$
}

Eingegangen am 28. Mai 1963 